\title{
GCU
}

Glasgow Caledonian

University

University for the Common Good

\section{Microcredit as a public health initiative? Exploring mechanisms and pathways to health and wellbeing}

Ibrahim, Fatma; McHugh, Neil; Biosca, Olga; Baker, Rachel; Laxton, Tim; Donaldson, Cam

Published in:

Social Science and Medicine

DOI:

10.1016/j.socscimed.2020.113633

Publication date:

2021

Document Version

Author accepted manuscript

Link to publication in ResearchOnline

Citation for published version (Harvard):

Ibrahim, F, McHugh, N, Biosca, O, Baker, R, Laxton, T \& Donaldson, C 2021, 'Microcredit as a public health

initiative? Exploring mechanisms and pathways to health and wellbeing', Social Science and Medicine, vol. 270, 113633. https://doi.org/10.1016/j.socscimed.2020.113633

\section{General rights}

Copyright and moral rights for the publications made accessible in the public portal are retained by the authors and/or other copyright owners and it is a condition of accessing publications that users recognise and abide by the legal requirements associated with these rights.

Take down policy

If you believe that this document breaches copyright please view our takedown policy at https://edshare.gcu.ac.uk/id/eprint/5179 for details

of how to contact us. 


\section{Microcredit as a public health initiative? Exploring mechanisms and pathways to health and wellbeing}

Corresponding author

Fatma Ibrahim.

PhD candidate at the Yunus Centre for Social Business and Health- Glasgow Caledonian University.

Email: Fatma.ibrahim@gcu.ac.uk

Co-authors:

Neil McHugh. Reader in the Yunus Centre for Social Business and Health, Glasgow Caledonian University.

Olga Biosca. Reader in the Yunus Centre for Social Business and Health at Glasgow Caledonian University.

Rachel Baker. Professor of Health Economics and Director of the Yunus Centre for Social Business and Health at Glasgow Caledonian University.

Tim Laxton. PhD candidate at the School of Health and Life Sciences at Glasgow Caledonian University.

Cam Donaldson. The Yunus Chair in Social Business and Health at Glasgow Caledonian University and Pro Vice-Chancellor Research.

Note: This project (Fair credit, health and well-being: eliciting the perspectives of low-income individuals') has received funding from the Chief Scientist Office (Scotland) project reference number CZH/4/1095. 


\section{Abstract}

The widening health gap between the best and worst-off in the UK requires innovative solutions that act upon the social, economic and environmental causes of ill-health. Initiatives such as microcredit have been conceptualised as having the potential to act on the social determinants of health. However, pathways that lead to this impact have yet to be empirically explored. People living on low incomes, who are financially-excluded, require access to credit to cope with everyday financial needs. While research shows the connections between debt and health, this link is often focused on overindebtedness and negative health outcomes. In this paper, we investigate the impact of responsiblydelivered credit on the health and wellbeing of borrowers. In 2016-17, in-depth, semi-structured interviews were undertaken with fourteen borrowers from two microcredit providers offering personal and business microloans, operating in Glasgow, United Kingdom. Findings are presented, using social determinants of health as an analytic lens, and illustrated in a conceptual model explaining the loan mechanisms and pathways connecting microcredit to health and wellbeing. Microcredit, and the mechanisms through which it is delivered, were perceived by participants as positively impacting on their health and wellbeing. Access to flexible, responsibly-delivered, microloans enabled participants to plan and feel secure when faced with (un)expected financial events, reducing the associated stress, sustaining social relationships and empowering borrowers to take greater control over their lives. For some, receiving microcredit was stressful, as it is still a debt that needs to be repaid. Such stress can also be exacerbated by particular aspects of the lending model; for example, group lending. Our results contribute to growing evidence on the impact of financial inclusion approaches on health and wellbeing, highlighting the potential role of microcredit as a public health initiative and the need to support 'alternative' economic spaces in the UK to serve the financially-excluded.

Keywords: Microcredit; financial inclusion; health and wellbeing; conceptual models, qualitative research; United Kingdom 


\section{Introduction}

In the UK, health gaps exist and are widening between the best and worst-off in society (Marmot, 2010). As health is determined by social, economic and environmental factors, there is a need to identify new initiatives that could alleviate complex, interactive processes and systems which lead to ill health (Dahlgren and Whitehead, 2007; Popay et al., 2008). One symptom and cause of poverty is financial exclusion (Scottish Executive 2005; Dobbie and Gillespie, 2010). Financially-excluded individuals have difficulty accessing and using appropriate and affordable financial products and services that meet their needs (Leyshon, 2009; Sinclair, 2013; Rowlingson and McKay, 2017). Instead, these individuals typically utilise: personal networks, such as friends or family, for informal loans (Biosca et al., 2020); sub-prime payday and doorstep lenders, offering credit at high rates of interest (Leyshon et al., 2004; Fuller and Mellor, 2008); and/or 'go without' by, for example, cutting back on food (Gibbons, et al., 2011). However, these coping mechanisms risk worsening financiallyexcluded individuals' health and wellbeing. (Relatively) high-priced debt is associated with worse health (Sweet et al., 2013). Informal lending from homophilic peers could lead to feelings of shame and guilt that negatively affect these important but fragile social relationships (Money and mental health, 2018; Biosca et al., 2020). Being in financial difficulty is linked to increased stress and anxiety (Meltzer et al., 2002; Kempson et al., 2004). Approaches to financial inclusion are recognised as a potential way to impact on health; however, most research tends to focus on the provision of financial advice (Adams et al., 2006; Dobbie and Gillespie, 2010). Another response to financial exclusion in modern welfare states of Europe is the provision of microcredit (Lenton and Mosley, 2012). Microcredit can be defined as a small loan provided at affordable interest rates to individuals who cannot access mainstream lenders due to a lack of collateral and/or credit history. This atypical form of lending is considered as having the potential to impact on borrowers' health and wellbeing by acting on upstream determinants of health (McHugh et al., 2017). In this paper, we empirically explore the perceived impact of microcredit on health and wellbeing and the underlying mechanisms that facilitate this impact, contributing to the growing evidence on the impact of financial inclusion approaches on health and wellbeing. 
In what follows we first outline the relationship between debt and health and explain the need to explore the role of specific forms of debt, such as microcredit, in this. Microcredit in the UK is then introduced, and the potential of microcredit impacting on health and wellbeing considered. The methods and findings of a qualitative interview study, with borrowers of two UK microcredit institutions, are then reported using social determinants of health as an analytic lens to examine results.

\section{Background}

\subsection{Debt and health}

There is a growing body of work exploring the relationship between debt and health, with the former increasingly recognised as a socioeconomic determinant of the latter (Fitch et al., 2010; Sweet et al., 2018a). Several studies have found an association between debt and worsening mental health outcomes, such as stress, depression and distress (for example, Drentea and Lavrakas, 2000; Reading and Reynolds, 2001; Brown et al., 2005; Zimmerman and Katon, 2005; Sweet et al., 2013). Other studies have found links between debt and poor physical and self-reported health (O’Neil et al., 2006; Munster et al., 2009). While psychosocial stress and over-indebtedness are suggested pathways through which these impacts may occur (Munster et al., 2009; Selenko and Batini, 2011; Sweet et al., 2018a; 2018b), limited research has qualitatively explored how debt impacts health. One reason why this is important is that not all types of debt, types of lenders or types of borrowers are the same (Sweet et al., 2018b). For example, debt can be for consumer or business purposes, secured or unsecured, taken over the short or long-term, have different repayment terms with credit issued by organisations with different missions, e.g. for-profit versus social, to individuals across the socioeconomic spectrum. This paper focuses, specifically, on the provision of microcredit in the UK to people living on low incomes who are financially vulnerable. 


\subsection{Microcredit, health and wellbeing}

\subsubsection{Microcredit in the UK}

Microcredit enables financially-excluded individuals to access loans that facilitate self-employment and smooth consumption (Armendariz and Morduch, 2010). Responsible finance providers are the main providers of microcredit in the UK (Responsible Finance, 2017). These institutions differ from other affordable-credit providers, such as credit unions, as they target individuals at the lower-end of the market as opposed to relatively more-affluent households, do not require borrowers to be members and cannot take deposits (Dayson et al., 2020; Carnegie, 2020). It is difficult to give a precise overview of the UK microcredit sector because there is no agreed-upon definition of microcredit in the UK or Europe (McHugh et al., 2014; Pedrini et al., 2016). There are 50 responsible finance providers operating in the UK; around 20\% providing personal microcredit, over 50\% providing some form of business microcredit, and the remaining providing loans for social enterprises and home development purposes. (Responsible Finance 2017; 2019; Dayson et al., 2020)

\subsubsection{The potential of microcredit to impact health and wellbeing}

Microcredit is an atypical form of lending. While the outcomes of providing microcredit are around income-generation, self-employment and consumption smoothing (Armendariz and Morduch, 2010; Lenton and Mosley, 2012; Biosca et al., 2020), UK lenders have been conceptualised as alternativeoppositional institutions (McHugh et al., 2019a). Alternative-oppositional institutions are differentiated from mainstream lenders, such as banks, and other forms of sub-prime lenders, such as payday or doorstep lenders, as the wellbeing and interests of borrowers, are prioritised above maximisation of profit (Lee, 1999; Fuller and Jonas, 2003). This socially-orientated form of lending typically operates with more expensive and intensive relationship-banking practices to assess creditworthiness, in contrast to credit-scoring technologies, so that the financially-excluded are lent to responsibly (McHugh et al, 2019a). This form of lending is proposed as having potential to act as a public health initiative by impacting on social determinants of health (Roy et al., 2016; McHugh et al, 2017). Instead of microcredit acting more instrumentally and directly on health by, for example, providing improved access to healthcare and incorporating health-related services, such as health 
insurance, health savings, or health education, into the delivery of microfinance (Leatherman et al., 2012; Lorenzetti et al., 2017), microcredit, in and of itself, is thought to impact on health through specific mechanisms and pathways. Mechanisms refer to characteristics associated with loan design and service operationalisation, while pathways refer to ways and routes through which health and wellbeing are affected by microloans, such as material resources, employment and working conditions, as well as social support networks, all of which are recognised determinants of health.

Research investigating links between microfinance and health has shown a connection between microcredit services and health and wellbeing improvements, via intermediate outcomes such as increased social connectedness, (Pronyk et al., 2008) and empowerment (Ngo and Wahhaj, 2012). Positive mental health effects, such as reduced depressive symptoms and reduced likelihood of depressive symptoms, have also been found from randomised controlled trials (RCTs) in South Africa and Mexico (Fernald et al., 2008; Angelucci et al., 2015). However, apart from the suggestion that repayment flexibility is related to mental stress (Field et al., 2012), there is limited insight into how microcredit affects health and wellbeing through social determinants. In general, research exploring loan mechanisms and pathways connecting microcredit and health and wellbeing is novel, particularly in high-income countries (Mohindra and Haddad, 2005; McHugh et al, 2017).

In this paper, we qualitatively explore the different narratives and views of microcredit borrowers, on the possible associations between accessing and managing a microloan and health and wellbeing, and the mediating mechanisms and pathways that might facilitate these associations. We focus on both health and wellbeing to acknowledge the overlapping nature of these terms (WHO, 1946) and to indicate our interest in both physical and mental health as well as broader aspects, such as control, empowerment and reduced stigma. The findings of this study contribute to the debt and health literature, the growing evidence on the impact of financial inclusion approaches on health and wellbeing and highlight the need to support 'alternative' economic spaces in the UK to serve the financially-excluded. 


\section{Methods}

\subsection{Study Setting and Sampling}

This study was undertaken in Glasgow city, in west-central Scotland, UK. Glasgow is renowned for the pronounced health inequalities that exist amongst its population (Walsh et al., 2010; McCartney et al., 2012; Whyte and Ajetunmobi, 2012) and for hosting a variety of financial institutions, and particularly credit unions. In this study, we were interested in the experience of people living on lowincome to whom even these services might be inaccessible. Our interest was in a small number of microcredit institutions in Glasgow $(\mathrm{n}=2)$ which offer different forms of microcredit and other financial products to financially-excluded individuals. At the time the study was undertaken, Glasgow was where the main providers of microcredit were located in Scotland.

This qualitative study is part of a larger multi-method (financial diaries, qualitative interviews and Q methodology) research project (FinWell:Fair credit, health and well-being: eliciting the perspectives of low-income individuals'). This paper focuses on in-depth, face-to-face, interviews with microcredit borrowers. Results from other parts of the project are published elsewhere (see Mchugh et al., 2019b and Biosca et al., 2020).

The larger, first stage of research, was a diary study which included 45 participants, who, rather than being statistically representative of Glasgow's population, were selected to achieve maximum variation (Given, 2008) in terms of (a) participation in microcredit (business microloans, personal microloans, financial advice and non-users), (b) socio-demographic characteristics, (c) disability and health status, and (d) neighbourhoods around Glasgow (for more detail see Biosca et al., 2020). Invitations to take part in the study were issued through gatekeepers. The gatekeepers were:

1- Grameen in the UK, offer small productive microloans (from $£ 1000$ to $£ 5000$ ) to groups of five borrowers. Repayments are made during weekly group meetings. Groups are required to have an elected chair to assure all members attend weekly meetings and pay back their loans. Loan distribution is subject to the formation of the group. To ensure loans are used for business purposes borrowers are asked for receipts as proof of investments. 
2- Scotcash, offer small personal individual loans. Repayments are made through direct debits and arranged to suit borrowers' cash flow, for example matching repayment dates to when borrowers receive welfare benefits or salaries. Loans' amounts (from $£ 50$ to £500) and distribution are subject to affordability checks done on a case-by-case basis.

Loan officers in both institutions were asked to pass on project information (in writing and orally) along with contact details of the researchers.

Participants in (the FinWell research study) were from a hard-to-reach population, with experience of financial exclusion. Three researchers, OB, FI and TL, were responsible for diary data collection and, during the six-month diary study, they came to know the participants and their financial lives, building rapport and familiarity with participants' circumstances and experiences. A sub-sample of participants ( $\mathrm{n}=14)$ out the larger sample $(\mathrm{n}=45)$ were then purposively selected (Mason, 2017) to take part in the second phase of the study (qualitative interviews). Only participants who had received affordable business or personal microloans and who were known (from diaries data collection) to have different perceptions and experiences of these lenders were identified and recruited for this phase.

All participants who agreed to be interviewed were provided with an information sheet, given time and opportunity to ask questions and gave written consent to participation. Ethical approval was obtained from Glasgow School for Business and Society Ethics Committee, Glasgow Caledonian University (GCU) the 23rd March 2015 Ref no: GSBS EC 01.

\subsubsection{Participants}

Table 1 describes the sample in terms of the type of microcredit loan, number of microcredit loans, demographic characteristics and number of interviews. Fourteen interviews were conducted with six follow-up interviews which occurred 8-10 months after the $1^{\text {st }}$ interview. At the time of the first interview, seven participants were borrowing from the lender for the first time, four had used it twice and three had used it three times. By the time of the second round of interviews, four out of six repeated interviewees were continuing to use the service - repaying old loans and receiving new ones 
- while two had decided not to borrow from the microcredit institution as they had acquired a fulltime job and were able to access mainstream financial institutions and/or no longer required a loan due to their stable finances. Pseudonyms are used to anonymise participants.

\subsection{Data Collection}

Interviews were conducted between May 2016 and May 2017 and ranged in duration from 35 to 79 minutes, by the same researchers who collected diary data (OB, FI and TL). Interviews were based on a topic guide (see supplementary materials), used as an aide-memoire to support a guided conversation. Commencing with open-ended questions and using follow-up probes and prompts. The topic guide focused on: participants' financial situations prior to engaging with the microcredit institution; their experience of borrowing from microcredit institution; the relationship between finances and their health; and the perceived impact of borrowing from a microcredit institution. Follow-up interviews investigated in more depth their perceptions and experiences expressed in initial interviews, particularly in relation to potential pathways of impact connecting microcredit to health and wellbeing. Topic guides for follow-up interviews were tailored to each participant based on preliminary analysis of the first interview. Initially, participants found it difficult to articulate health and wellbeing effects and explain how they occurred - even though some participants had previously reported impacts to researchers during the completion of their financial diaries. The topic guide was therefore repeatedly revised, and, to facilitate discussion about health and wellbeing impacts, 'show cards' (containing words such as 'stress', 'happy' and 'empowered') were designed and presented to participants as 'things some people had said'. Participants were invited to select cards that they thought best described the impact of receiving a loan on their health and well-being and to talk about each one. While financial diaries enabled us to understand everyday financial details of participants (see Biosca et al., 2020 for details), qualitative interviews provided rich insights into participants' perspectives regarding using microcredit and its impact on their health and wellbeing. 


\subsection{Data Analysis}

All interviews were digitally recorded and transcribed in full (one interview was translated from Spanish), then were imported into NVivoPro V.11 software (QSR International's, 2015). Data cleaning and preparation were initially undertaken by revising transcripts while listening to audio records. During this process, data were indexed by creating data-driven, descriptive codes. A morefocussed coding process followed, with codes created around the study aims. From this initial coding framework, superordinate codes were constructed to gather similar sub-codes under higher-order codes which were used to develop themes.

Thematic analysis was used to identify patterns of similarity in participants' accounts of their experiences and views while preserving respondents' interpretations, language, and experiences (Braun and Clarke, 2006). Principles of constant comparison (Taylor and Bogdan, 1998) were used, as data collection and analysis were undertaken concurrently, to revise, refine and solidify themes with participants. Conflicting cases were identified and used to challenge and strengthen the analysis, and describe the nature of conflict as well as agreements (Seale, 1999). An empirically-informed conceptual model was developed based on participants' views and connections between themes. Findings were regularly reviewed by the research team, suggested modifications discussed and agreed upon and the coding framework, thematic findings and conceptual model revisited and updated accordingly. Following this descriptive analysis, we consider our findings in relation to literature on debt as being a socioeconomic determinant of health.

\section{Results}

Our findings indicate the importance of how microloans were accessed, administered, repaid and used for participants' health and wellbeing. These findings are outlined in a conceptual model in Figure 1 and categorised under four themes: (i) Antecedent circumstances - assembles participants' views on how their financial situations and health and wellbeing are interlinked; (ii) Mechanisms and use of microcredit - outlines loan mechanisms that are perceived by participants as leading to an impact on health and wellbeing (each mechanism is represented with a different colour); (iii) Intermediate 
outcomes - presents pathways which link loan mechanisms to health and wellbeing outcomes; and finally, (iv) Health and wellbeing-related outcomes - outlines how the interaction of the first three themes is perceived as impacting on five sub-categories of health and wellbeing; (a) control, (b) confidence, (c) stress and mental health, (d) feelings of self-worth and (e) social participation. Solid arrows in the framework represent perceived positive associations and intermittent dashed arrows show perceived negative associations. Importantly, outcomes are not always indirect results of loan mechanisms through intermediate outcomes. In some cases, loan mechanisms are perceived to impact directly on health and wellbeing. This is indicated in Figure 1 using direct arrows from loan mechanisms to health and wellbeing-related outcomes. 
Figure 1: Loan mechanisms and pathways from microcredit to health and well-being

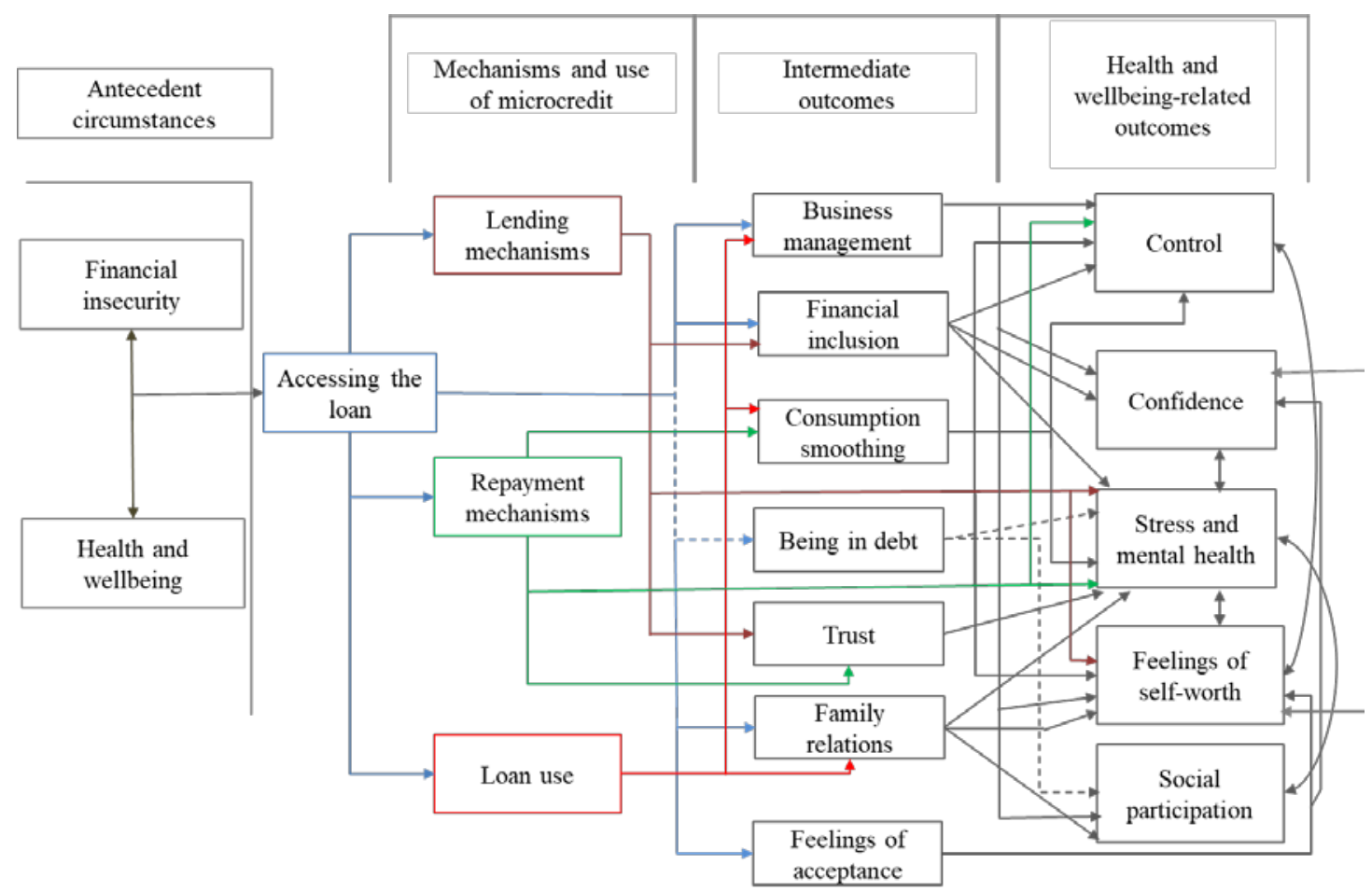

In the following, findings are presented in two main sections, the first sets out the context of our research questions in terms of our participants' lives (i) The precarious lives of the financiallyexcluded; and the second presents our main findings (ii) Microcredit, health and wellbeing: more than access to a loan.

\subsection{The precarious lives of the financially-excluded - antecedent circumstances}

Participants mostly lived on low-incomes, which for some were also irregular, limiting their ability to cushion for (un)expected expenditure peaks that they frequently experience. These include: necessary home repairs, attending a family gathering or a social event, bill arrears or Christmas gifts for children. Their precarious financial situations affected participants' health. Some struggled to afford daily basic needs and had the constant worry of making ends meet. They struggled to find suitable jobs and were unable to access capital to improve their financial circumstances by starting their own business: 
“...the strain does cause illness, depression, sickness, and it can be like a vicious circle then because you are not able to work, and I know for some people that aren't working but want to work but just can't get a job. I would say for them depression, and illness would be even higher because they don't have that stability in the finances that they have." (Hilary).

Inability to cushion for (un)expected expenses also led to negative mental health outcomes and longer-lasting dissatisfaction with life for some, as shown by reports of stress, sleeplessness, feeling pressure from making difficult financial decisions:

"I used to lie awake at night thinking I've got to get this money for him [a Christmas present for her son], what am I going to do for him? And that used to keep me awake at night and a really, really stressful time.” (Gillian).

Many with children, particularly single parents, also expressed feelings of shame and guilt if unable to provide for their children. This became so severe that some had suicidal thoughts. Allan, a single parent, realised that he might not be able to afford Christmas gifts for daughter that year:

"Dumps, down, down, ready for, I mean I was, I was ready to commit suicide aye. No personally for me for what I could not provide for my kid.” (Allan).

To meet necessary, and frequently time-sensitive, expenses participants often resorted to informal financial mechanisms, such as loans from family and friends, help from church or being part of a ménage (a variant of a ROSCA (Rotating Savings and Credit Association)). Credit unions were also inaccessible to participants, as often participants only required access to very small loans not offered by credit unions. Despite feeling that high-cost rent-to-own organisations, such as Perfect Homes, exploited their situation, participants used these organisations to purchase goods as they lacked access to other more affordable and timely solutions: 
“I know that they've got a high percentage [speaking of Perfect Homes interest rate], I know they pure rob you daylight. But, when you need it, you need it...” (Fiona).

Financial exclusion also increased stigma associated with belonging to a low-income group, being unemployed, an immigrant or receiving welfare benefits.

\subsection{Microcredit, health and wellbeing: more than access to a loan}

\subsubsection{Accessing the loan}

Participants' experiences of being rejected from mainstream financial institutions made them feel unworthy and stigmatised; thus they approached microcredit lenders with apprehension:

"I was feared in case they [Scotcash] knocked me back. I was going up there with the attitude that I've never been, they don't know me, they'll probably look at me because I look down, I look depressed, they'll probably say no to me.” (Allan).

Successful applications for microcredit loans made people feel accepted, improving feelings of selfworth as they perceived they were being given the same opportunity as others in society. For example, Mary, a 21-year-old British woman who needed money to decorate her flat, after living in homeless shelters for a few years and suffering from depression, thought that her loan request would be rejected and expressed shock when it was accepted.

Participants who received welfare benefits or were unemployed also unexpectedly felt respected as loan officers did not differentiate between them and other clients. Being financially-included through access to microloans increased participants' feelings of acceptance, reduced stigma, and increased their confidence:

“They don't make you feel as if you're different to other people, or different to them or that...They try and make you feel at ease and the whole process was quite good considering, I would say.” (Paul). 
This accessibility made it easier for participants, especially single parents, to plan for large expenses, reducing anxiety about coping with emergencies and creating a sense of security:

"I don't know how I can explain it. If they [Scotcash] weren't there, I'd get myself into so much stress and because I've got bad depression, I stress ... I stress when there's no need to stress at all. So, I know that I can fall back on them and they get me out of that hole. So, in a way, they lift me up for a couple of wee days. So, I know that I've got my weans' [children] Christmas in and then so in a way, they're [Scotcash] a wee anti-depressant.” (Fiona)

It also reportedly affected family relations positively as parents were able to afford everyday needs without asking for help from other family members - which for them would be an invasion of privacy or a source of embarrassment:

"I hate asking people for help. I could be actually ill, and I'll still just tackle through the day and everybody's like just sit down and I'm like no, I'll do it myself and they're trying to help me and I'm like, don't touch it, just leave it, I'm not an invalid I can do it. (Fiona)

When granting access to microloans, respondents felt motivated to undertake personal and professional projects. Especially for business loans, participants thought the loan allowed them to start and manage long-waited-for businesses, bringing a sense of control, confidence and reduced anxieties related to business management. It also increased social participation with greater control of working hours and having extra money for social activities.

However, for some borrowers, microcredit was viewed as another debt to be repaid and linked with increased stress levels. For Allan, the loan brought only short-term relief and the happiness from feeling "great for supplying for [his] kid's gifts" was diminished when he realised that he would soon have to pay the loan back, thinking that, although he could afford the loan instalment, it is high compared to his income (which came from Jobseeker’s Allowance). 


\subsubsection{Lending mechanisms}

Participants considered microcredit institutions' lending processes as clear, responsible, and straightforward. Loan officers were perceived as taking their time while providing all necessary information about the loan to ensure everything was understood, particularly with non-native English speakers. This was perceived as positively impacting on feelings of inclusion and self-worth, especially for immigrant borrowers.

In some cases, due to affordability concerns, loan officers judged that receiving a loan was not in the prospective borrowers' best interests, recommending postponement until financial circumstances changed. These interactions increased participants' trust towards the lenders, who were showing concern about their wellbeing, giving participants a sense of security that their interests were considered. Top-up loans, when a borrower needs another loan before fully repaying an outstanding amount, were also available for long-term customers. Knowing that a trusted source of finance was available whenever they needed it lowered feelings of anxiety and worry and increased feelings of security in case of emergencies:

"It makes me feel better, less stressful. Yes it gives you less stress that if there is a problem arise you know okay this money I can use it just solve this problem.” (Sabrina).

Additionally, the absence of hidden costs gave borrowers "peace of mind" (Rebecca), leading to a bond of trust between borrowers and loan providers which reduced stress associated with being in debt, especially with such tight financial situations.

\subsubsection{Repayment mechanisms}

Most participants perceived the interest rates from the two microcredit lenders, in comparison to other lenders they experienced, as fair and transparent:

“I used to, years ago, go to Provident [UK-based subprime lender] but they've ripped me off. The interest rates were terrible, I was paying back more than what I was actually getting, so I thought, never again. And it was my sister that put me onto Scotcash. And the interest is 
hardly anything, so it's not too bad, especially when I'm not working, so aye, they're fine." (Gillian)

However, even with fair interest rates, microloan repayments were a source of worry for some individuals on low incomes with a tight budget, with participants expressing a wish that they could meet their needs without resorting to borrowing money. Rebecca, who was already struggling with budgeting as a single mother, initially felt that Scotcash loan was "a step back" in her financial situation, as she was worried about not being able to make repayments. Flexibility around loan repayments helped ease her anxiety and stress, as reduced instalments could be paid over a longer time or repayment holidays taken. In contrast to other lenders, microcredit institutions were perceived as wanting to help borrowers with repayment difficulties, for example, refraining from going to borrowers' houses to demand repayment or shaming them about their predicament:

“I don't like the post coming to us for me to pay something [a reference to paying back a loan] and if you don't pay it stresses me so much. That is why I am stressed a little bit because I don't want the Grameen people to call me and say, “you are not paying”. But they didn't do that. Instead they ask me humbly how, do you have a problem? And I said, "yes" and they were waiting to help me and I had this peace.” (Jamila).

“...they give you your money and they try and help you as much as they can when you're in the [Scotcash] office... and you've got their number if you ever run into trouble, you needed anything or you need to stop the payments or something." (Gillian).

Participants were also aware that missed payments would not result in extra charges. This reduced the worry and pressure normally associated with debt and meant participants did not feel used to generate profit. However, not all microcredit repayment practices were viewed positively by participants. Some aspects of Grameen's group lending strategy were negatively perceived. The weekly frequency of these meetings was considered problematic. Finding time to meet each week was stressful due to the competing demands of looking after children and working. For some, meetings had a financial cost, 
particularly for travel (some groups being dispersed). Embarrassment was felt by group chairs when members failed to turn up or make repayments, causing stress to some participants:

"Worry, worried because there were weeks I could not attend the meeting and we had to go every week... and I was worried. Because I had to take the child with me and... it was on Wednesdays... and the child started school at one o'clock and.... We had to be in the group at 11 so I did not have much time to return to [another part of the city where the school is located]... then, yeah, worry." (Sofia).

On the other hand, some borrowers enjoyed and benefited from support offered by lending groups and felt motivated after meetings. A tangible benefit also came from being able to trade products and services among, and market businesses through, group members.

In contrast, Scotcash's individual-lending strategy was perceived positively by participants as it helped them to feel more in control over loan repayment and experience less worry about missing payments.

\subsubsection{Loan use}

While loan use was dependent on which microcredit lender was approached - personal (Scotcash) and business (Grameen) - participants viewed having a loan as an opportunity to improve their personal situation.

Personal loans were used to pay for (un)expected financial shocks, for consumption smoothing and help borrowers manage debts and gain control over their finances. Borrowers were able to provide for their children, particularly around Christmas or birthdays, which took a "weight off" (Allan) their shoulders and reduced stress caused by peak in consumption. Having extra money, even in the form of a loan, also meant some borrowers were more likely to socialise:

"With my health, it does make me feel a bit more happier, because I can go out. I can spend money without having to worry." (Mary). 
A longer-lasting benefit came from using Scotcash loans to pay-off other debts. This was made possible by Scotcash's more-flexible loans and lower interest rate (compared with other lenders), allowing participants to feeling in control over their finances which enabled future planning and gave borrowers some "breathing space" (Paul):

"...the loans help me, because they've got me out of this deep hole [reference to debt], so I'm not getting more depressed... I'll go into a deep, deep depression, and then Scotcash ... aye and then I've got Scotcash there to help me out. And then I'm lifted back up, it's like a brick took off you. It's like, a sigh of relief.” (Paul).

Business loans from Grameen were used to start-up, and invest in, small businesses, and helped borrowers manage existing businesses as well as other business-related debts. For some, business loans were perceived as "empowering” (Peter). Business loans allowed participants to take control over their lives, by providing the resources to transition from unemployment to self-employment.

There were several successful stories. For example, Ahmed used an initial loan from Grameen as a deposit on a car which he rented weekly as a taxi. This prospered, and within two years he was able to start a car rental company, with three cars of his own, and take on partners who also owned cars. Using Grameen loans for car loans enabled Ahmed to improve his credit score such that he qualified for a mortgage - Grameen "changed my life" (Ahmed). For businesses with cash flow difficulties, the loan enabled participants to limit asset-depleting strategies. This provided security and enabled participants to make more sales which in turn made the repayment of other debts easier and helped to stabilise finances.

While businesses were not always successful, participants felt proud for having started and achieved something on their own. This sense of autonomy and control over their lives helped them transition into salaried employment or start a different self-employment project. Becoming self-employed had, on occasions, a positive impact on family relations. For example, Amina, a single mother, was able to financially support herself and her two children through her business while gaining flexibility to spend more time with her children. 
A common outcome of taking either loan type was that participants gained independence, making them feel happier and prouder that they managed expenses or business on their own, instead of having to approach family members for money which also helped to improve family relations:

“The more profit I make out of that money I don't need to ask my sister or family or friends for anything. I have to do everything on my own which I am happy about. I am more secure about that side.” (Amina)

Our findings describe the financial stresses of people living on low incomes, briefly highlighting how precarious finances can affect physical and mental health in ways that are familiar from qualitative research into poverty, debt, and mental health. In a novel, qualitative exploration of microcredit, in the context of a high-income country, we present the impacts of microcredit described by borrowers: increased control, confidence, reduced stress and improved mental health, feelings of self-worth and social participation. These impacts map onto models of the social determinants of health (Wilkinson and Marmot, 2003; Szreter and Woolcock, 2004; Mann et al., 2004; McEwen et al., 2010; Woodall et al., 2010; Whitehead et al., 2016). We set out pathways of impact and point to loan and repayment mechanisms that contributed to positive and negative outcomes.

\section{Discussion}

This paper is the first to explore the perceived impact of UK microcredit on the health and wellbeing of borrowers and the associated mechanisms and pathways. Exploring borrowers' views of how microcredit impacts their lives provides important insights for considering microcredit as a socioeconomic determinant of health. Importantly, this also helps differentiate microcredit from other forms of debt and highlights the need for 'alternative’ economic spaces in the UK.

\subsection{Microcredit as a socioeconomic determinant of health}

Until incomes rise to a point that individuals can maintain a socially-acceptable standard of living, people living on low-incomes will continue to use and need credit to meet daily needs (Collard and Kempson, 2005; Gibbons, et al., 2011). However, those living on low-income are often excluded from 
mainstream financial institutions and tend to use high-priced alternatives such as payday lenders because it is available and convenient (Fuller and Mellor, 2008; Servon, 2017). Our findings reinforce the reasons why individuals are financially excluded, the precarious nature of their lives and highlight the wide-ranging negative impacts this has on their wellbeing (Collins et al., 2009; Sinclair, 2013; Morduch and Schneider, 2017). Individuals living on low-income require credit which is offered responsibly, designed to suit their needs and reduces their reliance on exploitative sub-prime lenders and informal loans from family and friends which can negatively impact health (Leyshon et al., 2004; Money and Mental Health, 2018; Biosca et al., 2020). This study highlights the potential of microcredit to fill that role and act as a positive socioeconomic determinant of health through the five outcomes highlighted in Figure 1.

Quantitative epidemiological studies highlight that debt is typically associated with negative mental and physical health impacts (for example, Drentea and Lavrakas, 2000; Reading and Reynolds, 2001; Zimmerman and Katon, 2005). Exploring how individuals experience debt and the meaning they attach to it is suggested as a way to understand how impact occurs (Sweet et al., 2018a). Unsurprisingly, given the links between health and unemployment, income, and financial difficulties (for example, Adler et al., 2002; Meltzer et al., 2002; Kempson et al., 2004; Marmot, 2010) loan use was perceived as impacting on health and wellbeing. However, our findings also highlight that access to flexible, responsibly-delivered, loans helped participants feel less marginalised, enabling them to plan and feel secure when faced with (un)expected financial events. By impacting on aspects of social exclusion, in terms of access to resources and having the capability to utilise them effectively (Popay et al., 2008; O’Donnell et al., 2018), the mechanisms through which microcredit are lent could impact positively on determinants of health. These findings stand in contrast to research exploring individuals' experience with other types of debt. For example, Sweet et al., (2018a) find that individuals experience of personal debt centres around strong feelings of shame, guilt and personal responsibility. This further highlights the importance of exploring the relationship between specific types of debt and health. 
As in the quantitative literature on debt and health, microcredit was not immune from having a perceived negative relationship with stress. Microcredit is, after all, a debt needing to be repaid which can be stressful, particularly for those with low incomes. Our results also highlight how aspects of repayment, such as group lending, could exacerbate stress if not convenient for borrowers. Importantly though, lending and repayment mechanisms of microcredit lenders are generally perceived positively, designed with borrowers' needs and circumstances in mind instead of profit maximisation. Both (studied) microcredit lenders also work to reduce chances that borrowers become overindebted through their responsible banking practices. This can help to reduce stress associated with being indebted and addresses the negative impact on health associated with over-indebtedness and long-term debt (for example, Munster et al., 2009; Fitch et al., 2010; Selenko and Batini, 2011; Clayton et al., 2015; Sweet et al., 2018b).

The empirically-informed conceptual model presented in Figure 1 illustrates pathways through which microcredit is perceived as affecting aspects of health and wellbeing. It should be stressed that this framework does not mean that all borrowers engaging with microcredit will be affected in the same way. Rather it provides a means by which to examine how these effects could occur for different ways of offering microcredit. While it is not claimed that microcredit alone will significantly 'dent' the entrenched health inequalities that exist in the UK, the importance of initiatives in non-health sectors is further emphasised, and the need to document the potential of such initiatives to impact positively on health. Our conceptual framework also provides the basis for future work in this nascent area. For example, the model does not include any aspects of physical health. While not unexpected, given the timescale over which data were collected, given the relationship between debt and physical health (for example, O’Neil et al., 2006; Munster et al., 2009), it would be interesting to explore in future research.

\subsection{The need for 'alternative' economic spaces in the UK}

The 2007-08 financial crisis led to 'new geographies of financial exclusion' being created which affected deprived areas subsequently targeted by exploitative 'sub-prime’ lenders (Aalbers, 2009; Appleyard, 2013; Rowlingson et al., 2018). To avoid further new geographies of financial exclusion 
being created following COVID-19, alternative financial institutions need to be supported. PreCOVID-19 these institutions already experienced issues with sustainability, as highlighted by the closure of Grameen in the UK following issues with cash flow (BBC, 2018). COVID-19 has put further pressure on business models of these providers. Increasingly, responsible finance providers are introducing online lending to expand market size (Carnegie, 2020; Dayson et al., 2020). Such changes are aimed at making responsible finance providers more competitive, by reducing costs, but can lead to them targeting marginally better-off individuals (Dayson et al., 2020), threatening the uniqueness of their relationship-lending model. For such alternative financial institutions to not only survive, but also develop and continue to support the most vulnerable in society, investment is needed. This could come through private mainstream banks being compelled to provide funds to alternative financial institutions through a Community Reinvestment Act (CRA), such as exists in the USA (Appleyard, 2013). Other options include direct government support in terms of subsidies or low cost, patient capital (Dayson et al., 2020). As responsible finance providers already respond to a financial market failure, evidence that this form of lending can positively impact on social outcomes, such as determinants of health, strengthens the case for more-favourable public policy consideration and support.

\subsection{Limitations}

This study has a number of limitations. Firstly, interviews focused on 14 borrowers from two MFIs operating in Glasgow that offered different products and used different mechanisms. While we do not claim our findings are generalisable or representative, we would argue for a degree of theoretical generalisability (Smith, 2018) and findings that merit further research to test or augment our model. Our empirically-informed conceptual model offers a starting point, mapping out pathways that can be explored and tested in different contexts. Secondly, due to constraints of the project, participants were recruited only after they received a microloan. However, respondents were asked to reflect on their experiences before receiving a loan. Lastly, and related to the previous issue, the relatively short time period over which repeated interviews were undertaken meant only perceived short-term effects could 
be explored. It would be interesting to follow borrowers longitudinally to explore the robustness of short-term effects and those that have a longer gestation period.

Microcredit borrowers found it more natural to articulate the immediate material impacts of their loans and how they felt about aspects of the products and repayments. Some spontaneously described the impacts on their health and wellbeing through reduced stress, social inclusion or acceptance and the improved wellbeing experienced through fulfilling their roles as providers and family members. With other participants, more probing follow-up interviews were needed and we introduced show cards to prompt explanation. There is a risk, in such approaches, of leading participants, which needs to be balanced with the ability to explore more-complex pathways of impact, which respondents may not otherwise perceive.

\section{Conclusion}

Whilst connections between microcredit and health have been explored in the literature, research to identify impacts of such loans within a determinants of health framework remains underdeveloped particularly in high-income countries such as the UK. In this paper, we investigate the perceived impact of responsibly-delivered credit on the health and wellbeing of borrowers and the pathways in which this impact may occur. Our findings contribute to the wider debt and health literature and provide evidence that responsibly-delivered credit can have a positive impact on the health and wellbeing of borrowers. The complex pathways that have been found to link different forms of microcredit to health and wellbeing can guide both practitioners and policy-makers as our results highlight the need to support 'alternative' economic spaces in the UK to serve the financiallyexcluded. The most visible consequences of financial exclusion such as 'going without', borrowing from friends and family, asset-depleting strategies and using high-cost credit have all been found to have a detrimental impact on the social determinants of health. Even although the association between microcredit and health and wellbeing varies depending on individual situations and is not always direct, we argue that alternative financial inclusion products such as microcredit can not only positively impact on the social determinants of health but also provide an alternative to the other 
available choices that financially-excluded people have, and are, therefore, worthy of even greater public policy consideration and support than they have received to date. 
Table 1: Characteristics of participants

\begin{tabular}{|c|c|c|c|c|c|c|c|c|c|}
\hline No. & $\begin{array}{l}\text { Respondent } \\
\text { (sex) }\end{array}$ & $\begin{array}{c}\text { No. of } \\
\text { Microloans }\end{array}$ & $\begin{array}{l}\text { Type of } \\
\text { loan }\end{array}$ & Age & $\begin{array}{l}\text { Marital } \\
\text { status }\end{array}$ & $\begin{array}{c}\text { Employment } \\
\text { status }\end{array}$ & Disability & $\begin{array}{l}\text { Welfare } \\
\text { Benefits }\end{array}$ & $\begin{array}{c}\text { No. of } \\
\text { Interviews }\end{array}$ \\
\hline 1 & Jamila (F) & 1 & $\begin{array}{c}\text { Business } \\
\text { loan }\end{array}$ & 54 & Single & $\begin{array}{c}\text { Self- } \\
\text { employed }\end{array}$ & No & Yes & 1 \\
\hline 2 & Allan (M) & 1 & $\begin{array}{l}\text { Personal } \\
\text { loan }\end{array}$ & 55 & $\begin{array}{l}\text { Single } \\
\text { parent }\end{array}$ & Unemployed & Yes & Yes & 2 \\
\hline 3 & Peter (M) & 1 & $\begin{array}{l}\text { Business } \\
\text { loan }\end{array}$ & 64 & Single & $\begin{array}{c}\text { Self- } \\
\text { employed }\end{array}$ & Yes & No & 2 \\
\hline 4 & Rebecca (F) & 2 & $\begin{array}{l}\text { Personal } \\
\text { loan }\end{array}$ & 21 & $\begin{array}{l}\text { Single } \\
\text { parent }\end{array}$ & Unemployed & No & Yes & 2 \\
\hline 5 & Gillian (F) & 3 & $\begin{array}{l}\text { Personal } \\
\text { loan }\end{array}$ & 53 & $\begin{array}{l}\text { Single } \\
\text { parent }\end{array}$ & Unemployed & No & Yes & 1 \\
\hline 6 & Ahmed (M) & 2 & $\begin{array}{c}\text { Business } \\
\text { loan }\end{array}$ & 43 & $\begin{array}{c}\text { Married } \\
\text { with } \\
\text { dependents }\end{array}$ & Employed & No & No & 2 \\
\hline 7 & Sabrina (F) & 2 & $\begin{array}{l}\text { Business } \\
\text { loan }\end{array}$ & 34 & $\begin{array}{l}\text { Single } \\
\text { mother }\end{array}$ & Employed & No & Yes & 2 \\
\hline 8 & Hilary (F) & 3 & $\begin{array}{l}\text { Business } \\
\text { loan }\end{array}$ & 42 & $\begin{array}{c}\text { Married } \\
\text { with } \\
\text { dependents }\end{array}$ & $\begin{array}{c}\text { Self- } \\
\text { employed }\end{array}$ & Yes & Yes & 2 \\
\hline 9 & Paul (M) & 2 & $\begin{array}{l}\text { Personal } \\
\text { loan }\end{array}$ & 53 & Single & Unemployed & Yes & Yes & 1 \\
\hline 10 & Alex (M) & 1 & $\begin{array}{l}\text { Personal } \\
\text { loan }\end{array}$ & 37 & $\begin{array}{c}\text { Married } \\
\text { with } \\
\text { dependents }\end{array}$ & Unemployed & Yes & & 1 \\
\hline 11 & Fiona $(\mathrm{F})$ & 1 & $\begin{array}{l}\text { Personal } \\
\text { loan }\end{array}$ & 26 & $\begin{array}{l}\text { Single } \\
\text { mother }\end{array}$ & Unemployed & Yes & Yes & 1 \\
\hline 12 & Mary (F) & 3 & $\begin{array}{l}\text { Personal } \\
\text { loan }\end{array}$ & 21 & Single & Unemployed & Yes & Yes & 1 \\
\hline 13 & Amina (F) & 1 & $\begin{array}{c}\text { Business } \\
\text { loan }\end{array}$ & 31 & $\begin{array}{l}\text { Single } \\
\text { mother }\end{array}$ & $\begin{array}{c}\text { Self- } \\
\text { employed }\end{array}$ & No & Yes & 1 \\
\hline 14 & Sofia (F) & 1 & $\begin{array}{l}\text { Business } \\
\text { loan }\end{array}$ & 41 & $\begin{array}{l}\text { Single } \\
\text { mother }\end{array}$ & Employed & No & Yes & 1 \\
\hline
\end{tabular}




\section{References}

Aalbers, M. (2009). Geographies of the financial crisis. Area 41, 34-42.

Adams, J., White, M., Moffatt, S., Howel, D., and Mackintosh, J. (2006). A systematic review of the health, social and financial impacts of welfare rights advice delivered in healthcare settings. BMC Public Health, 6(1), 81. https://doi.org/10.1186/1471-2458-6-81

Adler, N. E., and Newman, K. (2002). Socioeconomic disparities in health: pathways and policies. Health Affairs, 21(2), 60-76.

Angelucci, M., Karlan, D., and Zinman, J. (2015). Microcredit Impacts: Evidence from a Randomized Microcredit Program Placement Experiment by Compartamos Banco. American Economic Journal: Applied Economics, 7(1), 151-182.

Armendáriz, B., \& Morduch, J. (2010). The economics of microfinance. MIT press.

Appleyard, L. (2013). The geographies of access to enterprise finance: the case of the West Midlands, UK. Regional Studies, 47(6), 868-879.

BBC. (2018). Micro-finance provider Grameen Foundation Scotland folds. BBC News. https://www.bbc.co.uk/news/uk-scotland-scotland-business-46635722 [accessed 09 May 2020].

Biosca, O., McHugh, N., Ibrahim, F., Baker, R., Laxton, T., Donaldson, C., 2020. Walking a tightrope: using financial diaries to investigate day-to-day financial decisions and the social safety net of the financially excluded. The ANNALS of the American Academy of Political and Social Science, 689(1),, pp. 46-64.

Braun, V. and Clarke, V. (2006). Using thematic analysis in psychology, Qualitative Research in Psychology, 2, 3, 77-101.

Brown, S., Taylor, K., and Price, S. W. (2005). Debt and distress: Evaluating the psychological cost of credit. Journal of Economic Psychology, 26(5), 642-663. 
Dahlgren, G., and Whitehead, M. (2007). A framework for assessing health systems from the public's perspective: the ALPS approach. International Journal of Health Services, 37(2), 363-378.

Dayson, K. T., Vik, P. M., and Curtis, J. M. (2020). Scaling up the UK personal lending CDFI sector: from£ 20m to£ 200m in lending by 2027. h t tp://usir.salfor d.ac.uk/id/e print/56 51 o/ [accessed 01 December 2020]

Dobbie, L., and Gillespie, M. (2010). The health benefits of financial inclusion. Report for NHS Greater Glasgow and Clyde.

Drentea, P., and Lavrakas, PJ. (2000). Over the limit: the association among health, race and debt. Social science and medicine, 50 (4), 517-529.

Carnegie. (2020). Fear and Loaning Impact of Covid-19 on affordable credit providers serving financially vulnerable customers. Carnegie UK Trust and Community Finance Solutions, University of Salford. https://d1ssu070pg2v9i.cloudfront.net/pex/carnegie_uk_trust/2020/08/17120904/Fear-andLoaning-Impact-of-Covid-19.pdf [accessed 01 December 2020]Clayton, M., Liñares-Zegarra, J., and Wilson, J. O. (2015). Does debt affect health? Cross country evidence on the debthealth nexus. Social science and medicine, 130, 51-58.

Collins, D., Morduch, J., Rutherford, S., and Ruthven, O. (2009). Portfolios of the Poor: How the World's Poor Live on \$2 a Day. Princeton University Press.

Collard, S., and Kempson, E. (2005). Affordable credit: The way forward. Policy Press.

Fernald, L. C., Hamad, R., Karlan, D., Ozer, E. J., and Zinman, J. (2008). Small individual loans and mental health: a randomized controlled trial among South African adults. BMC Public Health, 8(1), 409.

Field, E., Pande, R., Papp, J., and Park, Y. J. (2012). Repayment flexibility can reduce financial stress: a randomized control trial with microfinance clients in India. PloS one, 7(9), e45679. 
Fitch, C., Chaplin, R., and Tulloch, S. (2010). The Debt and Mental Health Evidence Form: a tool for health professionals and lenders dealing with customers with self-reported mental health problems. The Psychiatrist, 34(3), 95-100.

Fuller, D. and Jonas, A. (2003). Alternative financial spaces. In: Leyshon, A., Lee, R., Williams, C. (Eds.) Alternative Economic Spaces. SAGE Publications, London, pp. 55-74.

Fuller, D., and Mellor, M. (2008). Banking for the poor: addressing the needs of financially excluded communities in Newcastle upon Tyne. Urban Studies, 45(7), 1505-1524.

Gibbons, D., Vaid, L., and Gardiner, L. (2011). Can consumer credit be affordable to households on low incomes? London. Centre for Responsible Credit and Friends Provident Foundation. https://www.responsible-credit.org.uk/wp-content/uploads/2016/04/can-consumer-credit-beaffordable-to-low-income-households-final-report.pdf [accessed 01 December 2020]

Given, L.M. ed. (2008). The Sage encyclopaedia of qualitative research methods. Sage publications.

Kempson, E., McKay, S., and Willitts, M. (2004). Characteristics of families in debt and the nature of indebtedness (No. 211). Leeds: Corporate Document Services.

Leatherman, S., Metcalfe, M., Geissler, K., and Dunford, C. (2012). Integrating microfinance and health strategies: examining the evidence to inform policy and practice. Health Policy and Planning, 27(2), 85-101.

Lee, R. (1999). Local money: geographies of autonomy and resistance? In: R. Martin (Ed.) Money and the Space Economy. Wiley, Chichester. pp. 207-224.

Lenton, P. and Mosley, P.(2012). Financial Exclusion and the Poverty Trap: Overcoming Deprivation in the Inner City. London and New York: Routledge.

Leyshon, A., Burton, D., Knights, D., Alferoff, C., and Signoretta, P. (2004). Towards an ecology of retail financial services: understanding the persistence of door-to-door credit and insurance providers. Environment and Planning A, 36(4), 625-645. 
Leyshon, A. (2009). Financial exclusion. In: Kitchin, R., Thrift, N., (Eds). International Encyclopaedia of Human Geography, Elsevier, Oxford, 4, 153-158

Lorenzetti, L. M., Leatherman, S., and Flax, V. L. (2017). Evaluating the effect of integrated microfinance and health interventions: an updated review of the evidence. Health policy and planning, 32(5), 732-756.

Mann, M.M., Hosman, C.M., Schaalma, H.P. and De Vries, N.K. (2004). Self-esteem in a broadspectrum approach for mental health promotion. Health education research, 19(4), pp.357372.

Marmot, M. (2010) Fair Society: Healthy Lives. Strategic Review of Health Inequalities in England Post-2010. The Marmot Review. http://www.instituteofhealthequity.org/resourcesreports/fair-society-healthy-lives-the-marmot-review/fair-society-healthy-lives-full-reportpdf.pdf (accessed 27 October 2020).

Mason, J.(2017). Qualitative researching, Third ed. Sage.

McCartney, G., Collins, C., Walsh, D., and Batty, G.(2012). Why the Scots Die Younger: Synthesizing the Evidence. Public Health, 126, 459-470.

McEwen, B. S., and Gianaros, P. J. (2010). Central role of the brain in stress and adaptation: links to socioeconomic status, health, and disease. Annals of the New York Academy of Sciences, 1186, 190.

McHugh, N., Gillespie, M., Loew, J., Donaldson, C., 2014. First steps towards self-employment microcredit for enterprise in Scotland. Scottish affairs, 23(2), pp. 169-191.

McHugh, N., Biosca, O., Donaldson, C., 2017. From wealth to health: evaluating microfinance as a complex intervention. Evaluation, 23(2), pp. 209-225.

McHugh, N., Baker, R., \& Donaldson, C. (2019a). Microcredit for enterprise in the UK as an ‘alternative’economic space. Geoforum, 100, 80-88.]. 
McHugh, N., Baker, R., Biosca, O., Ibrahim, F., \& Donaldson, C. (2019b). Who knows best? AQ methodology study to explore perspectives of professional stakeholders and community participants on health in low-income communities. BMC health services research, 19(1), 35.]

Meltzer, H., Singleton, N., Lee, A., Bebbington, P., Brugha, T. and Jenkins, R. (2002) The Social and Economic Circumstances of Adults with Mental Disorders London: TSO.

Mohindra K.S. and Haddad, S. (2005). Women's Interlaced Freedoms: A Framework Linking Microcredit Participation and Health. Journal of Human Development, 2005, 6(3): 353-374.

Money and Mental Health. (2018). Informal Borrowing and Mental Health Problems. https://www.moneyandmentalhealth.org/wp-content/uploads/2018/05/Money-and-MentalHealth-Informal-borrowing-report.pdf. (accessed 27 October 2020).

Morduch, J., and Schneider, R. (2017). The Financial Diaries: How American Families Cope in a World of Uncertainty: Princeton University Press.

Munster, E., Ruger, H., Ochsmann, E., Letzel, S. and Toschke, AM. (2009) Overindebtedness as a marker of socioeconomic status and its association with obesity: A cross-sectional study. BMC Public Health 9:286.

Ngo, T. M. P., and Wahhaj, Z. (2012). Microfinance and gender empowerment. Journal of Development Economics, 99(1), 1-12.

O’Donnell, P., O’Donovan, D., and Elmusharaf, K. (2018). Measuring social exclusion in healthcare settings: a scoping review. International journal for equity in health, 17(1), 15.

O’Neill, B., Prawitz, A., Sorhaindo, B., Kim, J. and Garman, ET. (2006). Changes in health, negative financial events, and financial distress/financial well-being for debt management program clients. Financial Counselling and Planning 17:46- 63.

Pedrini, M., Bramanti, V., Minciullo, M., and Ferri, L. M. (2016). Rethinking microfinance for developed countries. Journal of International development, 28(2), 281-302. 
Popay, J., Escorel, S., Hernández, M., Johnston, H., Mathieson, J., Rispel, L. (2008). Understanding and tackling social exclusion. Final report to the WHO Commission on Social Determinants of Health from the Social Exclusion Knowledge Network: World Health Organization.

Preamble to the Constitution of the World Health Organization as adopted by the International Health Conference, New York, 19-22 June 1946; signed on 22 July 1946 by the representatives of 61 States (Official Records of the World Health Organization, no. 2, p. 100) and entered into force on 7 April 1948.

Pronyk, P. M., Harpham, T., Busza, J., Phetla, G., Morison, L. A., Hargreaves, J. R., Kim, J.c., Watts, C. H., and Porter, J.D. (2008). Can social capital be intentionally generated? A randomized trial from rural South Africa. Social science and medicine, 67(10), 1559-1570.

QSR International’s, 2015. NVivoPro V.11 (Computer Software).

Reading, R., and Reynolds, S. (2001). Debt, social disadvantage and maternal depression. Social science and medicine, 53(4), 441-453.

Responsible Finance. (2017). Responsible Finance: The industry in 2017. Responsible Finance. https://www.european-microfinance.org/sites/default/files/document/file/ResponsibleFinance-The-Industry-in-2017-2.pdf [accessed 01 December 2020]

Responsible Finance. (2019). Responsible Finance: The industry in 2019. Responsible Finance. https://responsiblefinance.org.uk/policy-research/annual-industry-report/] [accessed 01 December 2020]

Rowlingson, K., McKay, S. (2017). Financial Inclusion Annual Monitoring Report 2017. Friends Provident Foundation.

Rowlingson, K., Appleyard, L. and Gardner, J. (2018). Payday lending in the UK: the regul(aris)ation of a necessary evil? Journal of Social Policy, 45, 3, 527-543. 
Roy, M. J., Baker, R., and Kerr, S. (2016). Conceptualising the public health role of actors operating outside of formal health systems: The case of social enterprise. Social Science and Medicine, 172, 144-152.

Seale, C. (1999). Quality in qualitative research. Qualitative inquiry, 5(4), 465-478.

Servon, Lisa. (2017). The unbanking of America: How the new middle class survives. Houghton Mifflin Harcourt.

Selenko, E., and Batinic B. (2011). Beyond debt. A moderator analysis of the relationship between perceived financial strain and mental health. Soc Sci Med.73(12):1725-1732.

Scottish Executive. (2005) Financial Inclusion Action Plan, Edinburgh: Scottish Executive. https://images.template.net/wp-content/uploads/2016/02/02091546/Financial-InclusionAction-Plan-Example-PDF-Template-Free-Download.pdf. [accessed $28^{\text {th }}$ October 2020]

Smith, B. (2018). Generalizability in qualitative research: misunderstandings, opportunities and recommendations for the sport and exercise sciences, Qualitative Research in Sport, Exercise and Health, 10:1, 137-149.

Sinclair, S. (2013). Financial inclusion and social financialisation: Britain in a European context. Int. J. Soc. Soc. Pol. 33 (11/12), 658-676.

Sweet, E., Nandi, A., Adam, E. K., and McDade, T. W. (2013). The high price of debt: Household financial debt and its impact on mental and physical health. Social Science and Medicine, 91, 94-100.

Sweet, E., DuBois, L. Z., and Stanley, F. (2018a). Embodied neoliberalism: Epidemiology and the lived experience of consumer debt. International Journal of Health Services, 48(3), 495-511.

Sweet, E., Kuzawa, C. W., and McDade, T. W. (2018b). Short-term lending: Payday loans as risk factors for anxiety, inflammation and poor health. SSM-Population Health, 5, 114-121. 
Szreter, S., and Woolcock, M. (2004). Health by association? Social capital, social theory, and the political economy of public health. International journal of epidemiology, 33(4), 650-667.

Taylor, S. J., and Bogdan, R. (1998). Introduction to qualitative research methods: A guidebook and resource (3rd ed.). Hoboken, NJ, US: John Wiley and Sons Inc.

Walsh, D., Bendel, N., Jones, R., and Hanlon, P. (2010). Investigating a 'Glasgow Effect': Why do equally deprived UK cities experience different health outcomes? Glasgow Centre for Population Health.

Whitehead, M., Pennington, A., Orton, L., Nayak, S., Petticrew, M., Sowden, A., and White, M. (2016). How could differences in ‘control over destiny’ lead to socio-economic inequalities in health? A synthesis of theories and pathways in the living environment. Health and place, 39, 51-61.

Whyte, B., and Ajetunmobi, T.(2012). Still "The Sick Man of Europe"?: Scottish Mortality in a European Context 1950 - 2010, an analysis of comparative mortality trends. Glasgow Centre for Population Health.

Wilkinson, R. G., and Marmot, M. (Eds.). (2003). Social determinants of health: the solid facts. World Health Organization.

Woodall, J., Raine, G., South, J., and Warwick-Booth, L. (2010). Empowerment and health and wellbeing: evidence review

Zimmerman, F. J., and Katon, W. (2005). Socioeconomic status, depression disparities, and financial strain: what lies behind the income-depression relationship? Health economics, 14(12),11971215. 